\title{
A country of perpetual pilot projects
}

$\mathrm{W}$

hen it comes to moving health care practices forward efficiently, Canada is a country of perpetual pilot projects. We seldom move proven projects into stable, funded programs, and we rarely transfer the outcomes of pilot projects across jurisdictions. This approach is not serving our health care system well.

Our addiction to pilot projects began in 1975, born of good intentions, when Health Canada (then National Health and Welfare) launched the National Health Research and Development Program. ${ }^{1}$ The program was intended to finance health promotion and research into disease prevention to counterbalance the basic medical research approach of the Medical Research Council. Between 75\% and 80\% of this new budget supported peer-reviewed pilot projects, demonstration projects, symposia and workshops; often tackling topics like child abuse and elder care well ahead of their time.

Provinces also began their own basic and applied health research programs, including the inevitable pilot projects. More recently, private foundations have jumped in. All of these funding streams have launched thousands of pilot projects across the country - projects that usually die when their initial funding runs out, regardless of their merit.

That waste of time, talent and energy is the first tragedy of this approach. The second tragedy is that our provincial and territorial health silos have no horizontal collaborative mechanisms to share lessons learned from pilot projects across jurisdictions. If a project does become integrated into a provincial health budget, that initiative usually stalls at the border, no matter how strong the evidence of its success. New Brunswick's Extra-Mural Program, which delivers home health care is a good example that other provinces could learn from. The project started small in 1981, and by 1993 , it was offered across the province, becoming the health care delivery option of choice for more than 19000 clients in 2005-2006.

There is a reason that governments are leery about granting core funding to sustain programs that begin as pilots: their need for financial control. Governments fear that community-based projects are ripe for administrative abuses or fraud. They prefer to be able to jettison pilot projects if they attract too much criticism or when budget priorities shift. Although some of these funding concerns are legitimate, a sound pilot project with good outcomes should not disappear once completed. The knowledge gained from effective, evaluated projects deserves to be shared. Instead, we repeatedly reinvent the wheel in different jurisdictions.

Solving this complex problem is difficult, but possible. We need to share the results of these projects, both successes and failures. A central, publicly accessible registry of pilot projects and their evaluations would help. Such a registry might include short project descriptions, evaluations and contact information, stored at an open-access site.

We also lack a way to generalize the successful approaches developed by pilot projects and the will to act upon them widely. We need forums for the exchange of knowledge across jurisdictions that can then direct practices and generate interjurisdictional learning and evidence-based policy.

Canada's municipal sector understands this need. The Federation of Canadian Municipalities maintains a database of case and feasibility studies financed by Green Municipal Funds, so that its members can replicate these best practices. ${ }^{2}$ Municipal decisionmakers can take sustainable community tours to observe best practices for themselves. After seeing Vancouver's bike lanes, for example, a councillor from Grande Prairie, Alberta, realized that it would be easy to install bike lanes in her community.

In the public health sector, National Collaborating Centres have begun to offer opportunities for better knowledge transfer. The National Collaborating Centre for Aboriginal Health brought federal, provincial governments and Aboriginal representatives together to exchange knowledge about the social determinants of health. The National Collaborating Centre for Environmental Health drew together water inspectors from across Canada to pool their expertise. A curriculum offered at a Newfoundland regional meeting to train operators working on small drinking water systems is now being replicated in Alberta.

We need more of these opportunities to learn from each other's experience. We then need to turn successful pilots into effective programs, regardless of where they originated. At the moment, we are prisoners of poisonous, political jurisdictional in-fighting. This is intolerable. We cannot afford to remain a country of perpetual pilot projects, wasting the learning we need. We must adapt and adopt models that work. We need a nationwide registry of pilot projects and a mechanism to share best practices and discuss project outcomes regularly and frankly across jurisdictions.

\section{Hon. Monique Bégin PhD}

Professor Emeritus, Telfer School of Management,

University of Ottawa, Ottawa, Ont.

\section{Laura Eggertson BA}

Journalist

Noni Macdonald MD MSc

Section Editor, Public Health, CMAJ

With the Editorial-Writing Team (Paul C. Hébert MD MHSc, Matthew B. Stanbrook MD PhD, Ken Flegel MDCM MSc)

Competing interests: See www.cmaj.ca/misc/edboard.shtml for the EditorialWriting Team's statements. None declared for Monique Bégin.

We welcome hearing from readers who know about federal, provincial or territorial health-related pilot projects that went nowhere. We will consider posting information about such projects on our website.

\section{REFERENCES}

1. National Health Research and Development Program - evaluation report. Ottawa (ON): Health Canada; 1994.

2. Federation of Canadian Municipalities. Green Municipal Fund Approved Projects Database. Ottawa (ON): The Municipalities; 2008. Available: http://gmf.fcm.ca /Search/Search/Search.aspx?lang=e\%201 (accessed 2009 Apr. 28). 